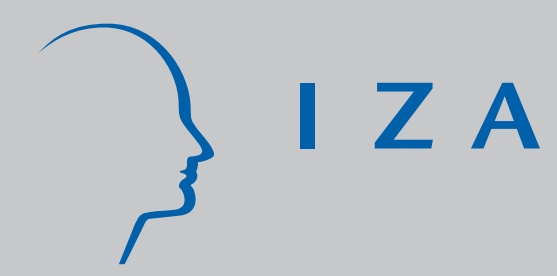

IZA DP No. 216

The Effects of Overeducation on Productivity in Germany - The Firms' Viewpoint

Felix Büchel

November 2000 


\title{
The Effects of Overeducation on Productivity in Germany- The Firms' Viewpoint
}

\author{
Felix Büchel \\ Max Planck Institute for Human Development, Berlin \\ and Technical University of Berlin
}

Discussion Paper No. 216

November 2000

\author{
IZA \\ P.O. Box 7240 \\ D-53072 Bonn \\ Germany \\ Tel.: +49-228-3894-0 \\ Fax: +49-228-3894-210 \\ Email: iza@iza.org
}

This Discussion Paper is issued within the framework of IZA's research area The Future of Work. Any opinions expressed here are those of the author(s) and not those of the institute. Research disseminated by IZA may include views on policy, but the institute itself takes no institutional policy positions.

The Institute for the Study of Labor (IZA) in Bonn is a local and virtual international research center and a place of communication between science, politics and business. IZA is an independent, nonprofit limited liability company (Gesellschaft mit beschränkter Haftung) supported by the Deutsche Post AG. The center is associated with the University of Bonn and offers a stimulating research environment through its research networks, research support, and visitors and doctoral programs. IZA engages in (i) original and internationally competitive research in all fields of labor economics, (ii) development of policy concepts, and (iii) dissemination of research results and concepts to the interested public. The current research program deals with (1) mobility and flexibility of labor markets, (2) internationalization of labor markets and European integration, (3) the welfare state and labor markets, (4) labor markets in transition, (5) the future of work, (6) project evaluation and (7) general labor economics.

IZA Discussion Papers often represent preliminary work and are circulated to encourage discussion. Citation of such a paper should account for its provisional character. 
IZA Discussion Paper No. 216

November 2000

\section{ABSTRACT \\ The Effects of Overeducation on Productivity in Germany- The Firms' Viewpoint}

Several firm-related aspects of employee productivity are analyzed using GSOEP data. The basic premise is that, as a consequence of frustration, overeducated employees are less productive than their correctly allocated colleagues. However, the results obtained in the present study contradict the few available empirical findings, all of which are based on data from the United States. When comparing employees working in jobs with similar levels of requirements (the sole approach which seems to be useful), overqualified employees are found to be healthier, more strongly work- and career-minded, more likely to participate in on-the-job training, and to have longer periods of tenure with the same firm than their correctly allocated colleagues. No significant differences could be determined with respect to job satisfaction. These findings are consistent with the established fact that overeducated workers receive wage premiums for their surplus schooling. The overall results make the hiring of overqualified applicants understandable, and could explain the employers' motivation to accept persistent overeducation in the labor force.

JEL Classification: J21, J24, J28, J63

Keywords: Overeducation, productivity, labor demand, job satisfaction, work- and careerorientation, health, on-the-job training, firm tenure

Felix Büchel

Max Planck Institute for Human Development

Lentzeallee 94

D-14195 Berlin

Germany

Tel: +49-30-82406-427

Fax: +49-30-8249939

Email: buechel@mpib-berlin.mpg.de 


\section{Introduction}

Overeducation in the labor market is a persistent problem in all industrialized countries (for an overview of this topic see, e.g., Freeman, 1976; Rumberger, 1981) ${ }^{1}$. The fact that many members of the labor force have a higher level of qualification than is required for their jobs leads to various negative outcomes. A major effect is that the overall economic productivity falls short of the limit set by the overall educational level of the employed population.

In a microeconomic framework, there are two ways of measuring the effects of overeducation on productivity. The first approach focuses on individuals, and uses a standard research design based on human capital theory. The lower productivity of overqualified employees can be detected in the form of wage penalties. By splitting the human capital of employees into one component needed to perform their job (required education) and a second, unused component (surplus education), it is possible to compare the returns for both components. Findings obtained using this method are available for several countries. Almost all researchers report lower returns for surplus education than for required education. Nevertheless, the returns for surplus education are positive (cf., e.g., Duncan \& Hoffman, 1981; Hartog, 1985; Rumberger, 1987; Hersch, 1991; Alba-Ramirez, 1993; Kiker, Santos, \& de Oliveira, 1997; Daly, Büchel, \& Duncan, 2000)².

The second approach to measuring the effects of overeducation on productivity focuses on companies. Several dimensions of employee attitudes—measured at an individual level—are taken as proxies for their productivity. The assumption is that, as a consequence of frustration, overqualified employees have higher levels of job dissatisfaction, more health problems, and higher rates of shirking or absenteeism than their correctly allocated colleagues. In addition, they are expected to change jobs more often as a result of frustration and of being offered positions which are better suited to their formal qualifications and job requirements. In general, the existing literature confirms these hypotheses (see Section 2). All of these effects naturally reduce the overall productivity of firms employing overeducated workers. Therefore, the expectation is that firms will tend to avoid hiring overeducated applicants.

When the patterns of results obtained from these two different approaches are compared, a somewhat confusing picture emerges. On the one hand, overeducated employees receive a (small) premium for the surplus component of their human capital. From the viewpoint of classical production theory, this

1 For empirical findings about the occurrence of overeducation in several countries, see Groot \& Maassen van den Brink (2000). 
would signal that overeducation has minor positive effects on productivity, at least. On the other hand, company-focused studies indicate that overeducated employees show deficits in various productivity-related dimensions of working behavior.

Hartog (2000) writes: "It would be highly informative if we knew the effect of over- and undereducation on productivity, rather than on wages. Several studies have established a negative effect of overeducation on job satisfaction (Tsang et al., 1991). Tsang (1987) has estimated that reductions in aggregated job satisfaction reduce plant output, thus implying that overeducation reduces worker productivity. (...). It is regrettable that this is the only study to focus on productivity effects. It leaves the puzzle that overeducation should reduce wages rather than increase them." (p. 139; underlining in original text). Indeed, there is an obvious need for further research. The present study is an attempt to cast some light on this "puzzling" situation. The two main questions to be addressed are as follows: Why do firms hire overeducated persons in large numbers? And why do companies pay higher wages to overeducated employees than to their correctly allocated colleagues with similar working conditions?

\section{Background}

Up to now, empirical evidence about the effects of overeducation on productivity, rather than on earnings, has only been available for the United States (with very few exceptions, see below). As mentioned by Hartog, Tsang's (1987) study is the only existing attempt to measure productivity effects using company data.

Tsang's (1987) study was based on data gathered on the employees of 22 U.S. Bell companies over two years of observation in the period from 1981 to 1983 . He used a three-step approach to show a negative impact of overeducation on firm productivity. First, individual employee data were used to estimate the effect of overeducation on job satisfaction; in this context, job satisfaction was considered to be a proxy of employee work effort. Having found the expected negative effect (additionally controlling for age, sex, race, and education), Tsang created a job-satisfaction index for each firm. This index was based on the estimated parameters from the former model, and adjusted for structural inter-firm differences in the control variables mentioned (as well as the structure of occupations). In a third step, this job-satisfaction index was entered as an additional variable into a

$2 \quad$ Verdugo and Turner-Verdugo's (1989) findings of negative returns for the surplus education component were heavily criticized on account of methodological problems with the research design employed (see Cohn, 1992; Gill \& Solberg, 1992); Verdugo and Turner-Verdugo's (1992) reply was not convincing. 
Cobb-Douglas production function; the estimated parameter for this variable yielded the expected positive sign. To summarize, Tsang (1987) tried to demonstrate the negative impact of overeducation on firm output by linking two separate causal effects: a) that overeducated individuals show lower job satisfaction, and b) that those firms in which the personnel structure (including the proportion of overeducated workers) would lead one to expect a low average level of job satisfaction among the employees have lower levels of output.

Other studies take proxy approaches based on individual data, as is the case in the present study. Tsang, Rumberger, and Levin (1991) and Hersch (1991) found evidence that overeducated males have lower job satisfaction and clearer intentions to leave their firms than correctly allocated employees ${ }^{3}$. Hersch additionally reported that male and female overeducated workers were less likely to participate in on-the-job training.

Numerous earlier studies with a more general context are also available. For a general overview, see Rumberger (1981, p. 101ff.) and especially Tsang and Levin (1985, p. 96ff.). The main focuses in these studies were on the effects of overeducation on job satisfaction and health. However, other productivity-relevant issues such as shirking or absenteeism, drug use, industrial sabotage, and a higher readiness to take industrial action were also discussed (cf., e.g., Kornhauser, 1964; Vroom, 1964; Kasl, 1974; House, 1974; Coburn, 1975; Mangione \& Quinn, 1975; Quinn \& Mandilovitch, 1975). In general, authors confirm the hypothesis that overeducation negatively affects workers' behavior and thus presents a severe risk for the firms in question.

Beyond the wage penalty approach (cf., e.g., Schwarze, 1993; Büchel \& Weißhuhn, 1998; Büchel \& Mertens, 2000; Daly, Büchel, \& Duncan, 2000), there have hitherto been no representative analyses of the effects of overeducation on productivity in the Federal Republic of Germany. More general German studies that discuss productivity effects from the company viewpoint have placed no special focus on overeducation (Bodenhöfer, 1983; Rippe, 1984). The only study to address in any detail the company-specific effects of overeducation on productivity is that of Haugrund (1990). However, the fact that this is a case study of a single company and that it focuses on specific occupational groups (i.e., technicians and engineers) makes the application of its findings to the general situation in Germany problematic.

Nonetheless, the negative effects of overeducation on productivity identified by U.S. authors are assumed to apply in Germany as well. Overqualification is considered to be a major reason for the rejection of job applicants. Indeed, in his standard work for German labor economists, Franz (1991) 
states that"companies hesitate to hire overqualified employees, and with good reason; the expected dissatisfaction of such an employee could, for example, negatively affect his or her productivity (...) and it is more likely that he or she might intend to quit" (p. 211ff.; translation by F.B.). The tentative formulation of this passage seems to hint that Franz has some reservations about this thesis. Moreover, he does not indicate the source of his assertions-with good reason, as there is no evidence of the effects of overeducation in Germany, either in the field of personnel research or in the classic field of labor market research. The analysis presented in this paper is therefore a first in the field of German research on overeducation.

\section{Data and Methods}

\subsection{Database and Case Selection}

The empirical analysis is based on representative data from the German Socioeconomic Panel (GSOEP), conducted by the German Institute for Economic Research (DIW) in Berlin. This ongoing survey was started in 1984, when more than 12,000 individuals aged 16 or above were interviewed. Additional information on these individuals is collected annually with a broadly constant questionnaire. The main purpose of the study is to obtain longitudinal information, especially in the fields of educational and labor market behavior (for more details, see Wagner, Burkhauser, \& Behringer, 1993, or, more specifically, Projektgruppe Panel, 1995). This paper analyses the two West German subsamples "A" (Germans) and "B" (immigrants). The analysis of job satisfaction and health status is based on cross-sectional data from 1995, that of the importance of work and occupational success on cross-sectional data from 1994, the analysis of participation in on-the-job training is based on retrospective data for the periods 1987-1989 and 1991-1993 obtained in the interview years 1989 and 1993 respectively, and the analysis of firm tenure is based on longitudinal data spanning the period from 1984 to 1995 . The study is restricted to employees aged between 16 and 65 . Trainees and persons undergoing full-time or formal training are excluded.

\subsection{Operationalization of Overeducation}

A subjective approach was taken to the identification of overeducation. The GSOEP contains information about two types of formal qualifications: the level of (general) school-leaving certificate, and any qualifications acquired in the vocational school system or at university. The information about vocational or university qualifications is used to create an overeducation dummy variable by 
comparing any such qualifications with the employees' self-reports of the formal qualifications usually required to perform their job. If the formal qualification is substantially higher than the job requirements, the value of this variable is "yes," otherwise the value is "no." Naturally, the question then arises of what degree of magnitude constitutes a "substantial" difference. For the purposes of this study, the problem is greatly simplified in that only those working in low-skill jobs are analyzed (see below). In this analysis, these jobs are defined by the fact that no formal vocational or university qualifications are required. Thus, respondents with such qualifications can justifiably be classified as overeducated. Those who have neither vocational nor university qualifications are classified as correctly allocated, regardless of the level of their general school-leaving certificate. This construction of the overeducation dummy was validated when additional information about the occupational position (berufliche Stellung) was taken into account. ${ }^{4}$

\subsection{Dimensions of Productivity and Types of Jobs}

In this analysis, the following main dimensions of productivity—all of which are observable with standard microeconomic data sets-are analyzed: job satisfaction, health status, participation in onthe-job training, and length of tenure. In addition, the self-reported relative importance of work and occupational success on well-being and satisfaction is analyzed, as it is expected that these variables affect the productivity potential of workers as well (for construction of variables, see below). To identify the effects of overeducation on productivity as precisely as possible, it is important to ensure that the jobs or job requirements of the individuals observed are as similar as possible. Therefore, only people working in low-skill jobs requiring no formal qualifications (i.e., neither vocational nor university qualifications) were included in this analysis. This case selection is not too restrictive for an analysis of overeducation; in 1995, 89\% of overeducated West German employees were working in the low-skill job sector ${ }^{5}$.

\subsection{Models and Set of Covariates}

All dimensions of productivity were analyzed separately as dependent variables within a consistent framework. OLS, logistic regressions, and a log-linear survival model were used. A standardized set of socioeconomic status (SES) and labor market measures was entered as covariates in the models:

$4 \quad$ For the detailed categorization scheme see Büchel (forthcoming). Two individuals showing obviously inconsistent combinations of the three source variables were excluded from this analysis. Furthermore, the operationalization process creates a "grey" area in which it is very difficult to determine whether or not respondents are overeducated. 9.5\% of cases fitted this category, mainly those with a combination of "vocational degree acquired," "skilled blue- or white-collar worker," "(only) longer-term (nonformal) on-the-job training within firm required to perform the job" (the latter instead of the expected response "vocational degree required to perform the job"). A rather defensive approach was taken, and these workers were also excluded from the analysis. It can be assumed that the overall pattern of results of this study would have been even more pronounced if these workers, who are known to have a relatively high productivity, had been classified as overeducated (as would be the case in the standard two-variables approach). 
age, schooling, nationality, state of health, family status by sex (for women: terms of interaction controlling for household type), occupational status (blue or white collar), regional unemployment rate, and population density of place of residence. Our main interest, however, was how the overeducation status of employees influences the different indicators of productivity. The set of covariates was standardized for two reasons: first, because it can be assumed that a specific group of effects influences the productivity of workers regardless of its dimensions, and second, because standardization enhances the comparability of results.

Age was entered in two ways: age and age squared. The underlying assumption was that productivity is highest for middle-aged employees who have an optimal combination of career-related ambition and work experience.

In German labor market studies, the schooling of workers is usually split into two human capital components: general schooling and knowledge acquired in the vocational system (i.e., mainly the apprenticeship system) or at university. Contrary to the standard Anglo-Saxon approach, schooling is not traditionally measured by years, but by the qualifications obtained. People may leave the general school system with no qualifications-which is rare 6 , with a Hauptschule certificate (lower secondary school-leaving certificate), a Realschule certificate (intermediate secondary school-leaving certificate), or Abitur (upper secondary school-leaving certificate, giving access to higher education) ${ }^{7}$. In this study, the general schooling of all workers was controlled using these three categories. The lower the school certificate, the lower the expected productivity of the workers. All school-leavers may enter the vocational system, regardless of the existence or quality of their school-leaving certificate; those with Abitur have the additional option of studying at university. Those with vocational or university qualifications are-by definition—additionally classified as "overeducated," as all respondents in this study work in the low-skilled segment of the labor market. This implies that the vocational school or university related human capital component is fully covered by the overeducation variable .

Non-German workers are generally expected to be less productive than their German counterparts because of language and other assimilation problems.

\footnotetext{
5 Own calculations based on data from GSOEP; results not shown.

6 In this study, workers with no school-leaving certificate were assigned to the Hauptschule category.

7 A special form of Abitur is the Fachhochschulreife, which gives access to Specialized Colleges of Higher Education. In this study, individuals with this type of school-leaving certificate were assigned to the Abitur category.

8 The vast majority of overeducated workers in low-skill jobs have an apprenticeship qualification; it is very rare to find university graduates working in low-skill jobs in Germany (cf. Büchel \& Weißhuhn, 1998). For this reason, making any further distinction between vocational and university qualifications (i.e., grouping overeducated people according to the degree of their surplus education) would result in too small cell numbers.
} 
Workers with poor health status are expected to be less productive than others. In this study, health status is used both as a control variable and as a dependent variable. This might appear to suggest that this item is endogenous. However, the fact that the correlation between overeducation and health status emerging in the health model is both relatively weak and positive (see below) indicates that this potential problem can be overlooked or, at the very least, that it is only a minor problem. In this study, a poor state of health is assumed if the interviewee reports that his or her health status hinders the performance of daily activities "somewhat" or "considerably," as opposed to "not at all".

The workers' family background is also expected to impact on productivity. However, the effects are assumed to be gender-specific. Husbands are expected to develop stronger occupational ambitions and thus higher productivity than men living alone, as they take economic responsibility for a wife who typically does not have comparable earning opportunities. In general, wives are more strongly restricted in their labor supply than single women as a result of the time restrictions entailed in family-related activities. These effects are even stronger if there are (young) children in the household and for single mothers. Therefore, terms of interaction between family status and sex were constructed as follows: in reduced form for men ( $\operatorname{married}^{10}:$ yes/no), and in extended form-with additional consideration of the household type-for women (living alone; married with no children below the age of 16 in the household; single mother; married with children below the age of 16 in the household; other household types).

The occupational status of workers was only controlled in a simple way (white vs. blue collar). The expectation was that white-collar jobs would be more productive than blue-collar ones.

Beyond these SES measures, characteristics of the local labor market could also be expected to affect the productivity of workers. This was first taken into account by controlling for local unemployment rate (on the level of 75 West German Regions). ${ }^{11}$ The expected effects of the labor market situation on productivity are ambiguous. On the one hand, high local unemployment rates could enhance the productivity of workers, in the sense that they are glad to have a job at all (job satisfaction), and that because they worry about losing their jobs, they are more likely to take care of their health. Work and occupational success could become more important, and workers could stay with their company for longer than usual, thus conserving company-specific human capital. All of these factors could increase productivity. At the same time, the firms' need to provide on-the-job training for workers

\footnotetext{
9 See coding of the dependent variable "health status" below for exact information about the question posed.

10 Here, "married" includes living with a long-term partner; the label "married" is used for reasons of simplicity.

11 This information on the Raumordnungsregion level was supplied by the Federal Office for Building and Regional Planning

(Bundesamt für Bauwesen und Raumordnung BBR; formerly Deutsche Bundesforschungsanstalt für Landeskunde und Raumordnung $B f L R$ ) and matched to the GSOEP population by the author. Thanks go to the BBR and the Data Protection Commissioner of the DIW, who gave special permission to match the BBR information to specifically data-protected regional information in the GSOEP sample.
} 
could be reduced. However, converse effects might also be observed: high local rates of unemployment and the ensuing job insecurity could negatively affect job satisfaction and health status, and the perceived importance of work and occupational success could diminish in the context of economic depression.

Secondly, the population density of the place of residence was also controlled. In general, productivity in rural areas is expected to be lower than in big cities. Those with high occupational ambitions are attracted to high density areas, where they have better chances of finding a qualified job, e.g., in large companies with good training opportunities. However, the effect on job satisfaction and health status is not easy to hypothesize; urban/rural differences in mentality and access to medical support could also play a role. In this study, differences between rural and urban areas were controlled by a dummy variable with a value of "rural" for people living in communities with less than 50,000 inhabitants $^{12}$.

\subsection{Dependent Variables}

\section{Job Satisfaction}

The original GSOEP information on job satisfaction was presented on a ordered scale ranging from 0 (absolutely dissatisfied) to 10 (absolutely satisfied). Unfortunately, when using standard Probit or Logit models with ordered discrete dependent variables, the chi-square based score test for the proportional odds assumption turned out to be negative. Therefore, a reduction of information was necessary, resulting in the following three categories: low job satisfaction (values from 0 to 4 ), intermediate job satisfaction (5 to 7), and high job satisfaction (8 to 10). This recoded dependent variable was analyzed using an ordered Logit model (Greene, 1993, p. 672ff.).

\section{Health Status}

In the GSOEP, information about the respondents' state of health is available in various different forms. Previous research has shown that there are some validity problems with asking how the person feels at the time of the interview, as answers may be influenced by temporary conditions. Information with a higher degree of validity can be obtained by the following question: "Apart from short-term illnesses, does your health status hinder you in performing daily activities; for example, household work, paid work, or educational activities? If so, to what extent?" Response categories were: (1) "not 
at all", (2) "somewhat", (3) "considerably" (translation by F.B.). The main focus of interest was on the question of which of the respondents feel any health limitations, and which do not. For this reason, values (2) and (3) were grouped together and contrasted with value (1). This dependent variable was then analyzed using a binary Logit model.

\section{Importance of Work and Occupational Success}

The 1994 questionnaire contains the following question: "Which of the following issues are ... (1) most important; (2) important; (3) less important; (4) not at all important ... for your well-being and satisfaction?" (translation by F.B.). Eleven issues were listed, among them "work" and "occupational success." These two items seem to be highly correlated; however, they do not measure the same aspect. Obviously, employers may expect those workers who report that both items are very important to be the most productive. Nevertheless, workers who "don't like to work" (or don't like their current job) but do aim at occupational success and high social status could be expected to report that work is less important and occupational success very important for well-being and satisfaction. Because they are eager to achieve their aim, they could be highly productive in their current job as well, realizing that such behavior is crucial for their future career prospects. On the other hand, people who "like to work" or especially like their current job but are not very ambitious could also be highly productive. This could particularly apply to those overeducated workers in the low-skill job segment who specifically opted out of a stressful career in favor of a less demanding occupation $^{13}$. The descriptive results presented in Table 3 show that a substantial proportion of respondents indicate that work, but not occupational success, is important or very important for their well-being and satisfaction.

Both items were analyzed separately. Due to the very low number of (working) respondents who reported that work was "absolutely unimportant" (1.1\%), answers (3) and (4) in the "work" item were pooled. The recoded dependent variable was then analyzed using an ordered Logit model. Where the original "occupational success" item is concerned, the score test for the proportional odds assumption turned out to be negative. Therefore, answers (1) and (2) were also grouped together. The recoded variable was then analyzed using a binary Logit model ${ }^{14}$.

\footnotetext{
12 The original variable was the population density of the place of residence according to the BBR scale (Gemeindegrößenklasse). This variable is not available in the public use version of the GSOEP; again, the special permission of the DIW's Data Protection Commissioner was requested and is gratefully acknowledged.

13 Büchel (1998) found some evidence that this strategy is often chosen by highly-educated West German women with wellearning partners. Their overeducation status - which leads to losses in earnings-is compensated by non-monetary benefits such as less overtime, proximity to the workplace, and so on.

14 In the models of this sub-step, the health status covariate was gained from the 1995 interview (not asked in 1994). Sample selection effects due to panel attrition from 1994 to 1995 seem to be negligibly.
} 
Information about participation in on-the-job training measures was collected retrospectively for a three-year period in the 1989 and 1993 waves of GSOEP. Respondents were asked to report on the three most important training measures in which they participated during this period. In the specific context of the German training system, the formulation of the question makes it possible to assume that reported activities are more likely to involve ongoing than newly-initiated training. It can be expected that the more productive employees are selected to participate in training measures. In the analyzed data, the duration of the three most important training measures is available in a ranged form. Recoding on a metric scale would be made possible by taking the mid-range values. A Tobit model could then be run, simultaneously analyzing the probability of being selected for on-the-job training and the extent of the training measures (in terms of the overall duration of the training activities). However, a pre-test showed that the maximum-likelihood estimators of both a Tobit model and-after reduction of information-an ordered Logit model are highly unstable. This is probably due to the fact that only $5.5 \%$ of the respondents actually participated in on-the-job training. Thus, a further reduction of information was necessary. The variable analyzed in this step was a dummy variable, which indicated whether or not respondents performing a low-skill job were selected for on-the-job training during the observed three-year period; training measures lasting just one day were not taken into consideration. The information from the 1989 and 1993 waves was pooled. If a person was interviewed at both points of measurement, the 1989 information was used. Again, only persons who were employed over the whole observation period were selected. The dependent dummy variable was analyzed using a binary Logit model.

\section{Firm Tenure}

Information on firm tenure, usually obtained by retrospective questioning, was derived from longitudinal data in this study. This is because the overeducation status at the beginning of a period of employment, a crucial element in this analysis, cannot be identified using a retrospective research design. The subsample for this step of the analysis consisted of all respondents who started a lowskill job in the period from 1984 to 1994 . For these respondents, firm tenure was measured using a prospective approach. Note that this measure is company- rather than job-related: within-company promotions from a low-skill to a higher occupational level may occur without resetting tenure to zero at the time of promotion. Firm tenure was right-censored for those working in the same company at the end of the observation period (1995, or earlier in the case of panel drop-out). In this situation, the use of a duration model is appropriate. A pre-test with a non-parametric lifetable estimator showed that the $\log$ estimates plot (survival function) was approximately linear through the origin. This 
indicates that a parametric model with exponential distribution and time-constant effects is appropriate (Greene, 1993, p. 717ff.). This was confirmed by another pre-test in which a semiparametric Cox Proportional Hazard Model was used, and very similar results obtained (results not documented). Note that the reason for leaving the firm - that is, whether the move was employee- or company-initated - was not controlled for in the model, as this has no effect on the transaction costs incurred by the company. Covariates in this step were gained at time of firm entry.

\section{Empirical Results}

\subsection{Job Satisfaction}

The results of the ordered Logit model (Table 1) show that—when controlling for important SES measures-overeducated employees are no less satisfied with their (low-skill) job than their correctly allocated colleagues.

Respondents living in rural areas have higher job satisfaction than those living in more densely populated areas. This could be explained by urban/rural differences in value perceptions. People with a poor state of health are much less satisfied with their work than others, which is hardly surprising. This marked effect is probably due to the fact that some of these people are forced to continue working for financial reasons. Other characteristics such as age, schooling, sex, and family situation have no significant impact on job satisfaction.

\subsection{Health Status}

In low-skill jobs, overeducated persons more often give themselves a clean bill of health than correctly allocated workers (Table 2), although the effect is only significant at a $10 \%$ level. This finding indicates that the well-known positive correlation between educational level and health status is stronger than the negative effects of the stress factors associated with overeducation (e.g., psychological problems due to the renunciation of occupational goals or unaccustomed working conditions).

The only other significant effect in the model confirms the established fact that blue-collar workers have more health problems than white-collar workers. This is mainly due to the poorer working conditions of the former, and to socio-economically based differences in attitudes to life. 


\subsection{Importance of Work and Occupational Success}

Overeducated workers in low-skill jobs report work and occupational success to be more important for well-being and satisfaction than their correctly allocated colleagues (Table 3), although the effect is only significant at a $10 \%$ level. With respect to the work variable, this could be influenced by the fact that some of the overeducated respondents have voluntarily chosen to work in low-skill jobs, whereas their colleagues with no formal qualification are "forced" to do low-skill jobs to make their living. As for the occupational success variable, one could argue that better educated people-in contrast to their correctly allocated peers-already demonstrate a certain degree of careermindedness by gaining vocational or even university qualifications. Another explanation, applicable to both variables, is that the overeducated respondents in this study are a positively selected subgroup of those who are unable to find a job which fits their qualifications: in the well-established German welfare system, the alternate status of unemployment is a relevant option. Furthermore, one could argue that the importance of work and occupational success is positively correlated with the level of occupational qualification, regardless of the quality of the current job. If this were true, a positive correlation of overeducation with these two variables would also be expected when the level of job requirements was kept constant.

The results show more heterogeneity in the effects of overeducation on the perceived importance of work than on the perceived importance of occupational success. As expected, the middle-aged respondents feel work to be more important than the younger or older respondents. Those with Abitur, the highest school-leaving certificate-and certainly no preparation for low-skill jobs_-report that work is much less important than those with lower qualifications. It can be assumed that a substantial proportion of these respondents are working in a low-skill job on a casual basis, and planning to study at university at the same time. Unsurprisingly, married men report that work is more important, and wives with children in the household that it is less important, than do unmarried men. As for the occupational success variable, the only effect—beyond that of overeducation-was found for married men, who felt occupational success to be very important.

\subsection{On-the-Job Training}

Overeducated workers in low-skill jobs have significantly higher chances of being selected for onthe-job training measures than their correctly allocated colleagues (Table 4). This can be explained by the fact that overeducated persons have-by definition-higher formal qualifications than their colleagues. From the point of view of those decision-makers controlling finances-the personnel 
managers - the superior intellectual abilities of overeducated persons are associated with higher expectations for the effectiveness of the investment in additional human capital.

The results for the other covariates confirm well-known themes. Those with the highest schoolleaving certificate (Abitur) have high rates of participation in training measures. This pattern is consistent with the fact that an increasing number of German Abitur holders are chosing not take advantage of the opportunity to enter higher education, instead deciding to pursue a non-academic working career, beginning at a low occupational level. Although they lack vocational or academic qualifications, their above-average general school education gives them some advantages over other competitors. Non-Germans have much greater difficulty in being selected for training measures than German nationals, even when school level is controlled for. This may be due to language problems, but also to discrimination. Unsurprisingly, those with poor health are less likely to be selected for onthe-job training than others. As was also expected, those working in the white-collar sector engage in substantially more on-the-job training than blue-collar workers. Finally, the data show that the frequency of participation in training measures has increased over the last few years.

\subsection{Firm Tenure}

Overeducated workers in low-skill jobs show significantly longer firm tenures than their correctly allocated colleagues (Table 5). This finding could be explained by the fact that overeducated persons consider themselves fortunate to find a job, regardless of its quality. A voluntary decision to work in a job for which one is overeducated, but which has high non-monetary returns, could also play a role. Both interpretations are consistent with the results presented in Büchel (1998, p. 198ff.), whereby overeducated persons were significantly more likely to report that, "it would be difficult to find a comparable job in the case of a job loss" than correctly allocated persons.

The age effects are in line with the well-known fact that turnover is highest at the beginning of one's career. Non-Germans have longer firm tenures than Germans. Again, it can be assumed that nonGermans have difficulties in finding better jobs, and thus stay with their firm, protected by law against involuntary dismissal. As expected, married women with small children have atypically short firm tenures, obviously caused by time conflicts in the competing domains of work and childcare. This well-known result partly explains gender-specific differences in earnings among young workers; predicted tenure is a crucial factor in company decisions of whether or not to invest in companyspecific human capital. Finally, the results show that, as expected, white-collar workers have longer firm tenures than blue-collar workers. This is consistent with the finding in the previous step of the analysis that white-collar workers are more likely to participate in on-the-job training than blue-collar 
workers: companies try to preserve the skills acquired in on-the-job training - mainly firm-specific knowledge - by reducing the turnover of better qualified workers. This is evidently also the case in the low-skill segment of the labor market.

\section{Conclusions}

The findings of this study show that in Germany, overeducated employees in low-skill jobs (where almost all overeducated workers are to be found) tend to be more productive than their correctly allocated colleagues. This result is inconsistent with the findings of various U.S. studies, which seemed to identify severe productivity losses resulting from overeducation, on account of the effects of frustration.

The reason for this incongruity could be due to differences in approach. For example, Tsang (1987) analyzed job satisfaction as a function of years of acquired education, years of surplus education, and other covariates. Because of the well-known positive correlation between acquired education and job satisfaction, the result reported by Tsang (negative effects for surplus education) is not very surprising: the more surplus education, the lower the level of job requirements (when controlling for acquired education); and the lower the level of job requirements, the lower the job satisfaction. This relation is well-known, but does not answer the interesting question of whether overeducation per se lowers job satisfaction. It is evident that a sociologist working at McDonald's has a lower job satisfaction than a sociologist working at a research institute. The company-relevant question (and the question facing the personnel manager at McDonald's) is whether a sociologist working at McDonald's has a lower job satisfaction (and lower productivity scores on other company-relevant indicators) than an unqualified person doing a comparable job in the same company.

For this reason, the main focus of the present analysis was on keeping levels of job requirements comparable across the study. The result yielded by this approach-an overall positive effect of overeducation on productivity from the firms' point of view-is consistent with the findings of most earnings analyses, which show a (small) positive effect of surplus education on the individuals' income levels (see Section 1). Moreover, the results also exhibit a convincing inner consistency: when the level of job requirements is kept constant, overeducated persons by definition show a higher level of formal education than their correctly allocated colleagues. As a consequence, it is not surprising that they enjoy a better state of health (the positive correlation between education and health is established) or that they show higher rates of participation in on-the-job training (it is also established that better educated employees have higher chances of being selected for company- 
related training). Furthermore, taking into account the findings on the importance of work and occupational success as well as the findings on participation in on-the-job training, it is again unsurprising that overeducated employees show longer firm tenures, since it is well-known that participation in on-the-job training and attitudes such as career-mindedness enhance the likelihood of promotion within the firm.

These results can help to answer one major open question in overeducation research, namely, why firms hire overeducated workers in large numbers. If, as the results of this study suggest, overeducated employees are generally more productive than others, then it makes sense to hire them. Therefore, the overall results of this analysis tally with the expectations of the familiar jobcompetition model (Thurow, 1975): better educated people are expected to be more productive (and the present findings suggest they indeed are) and, as a consequence, to acquire positions at the upper end of the job queue. In addition, the overall result is consistent with the findings of Sicherman (1991) who showed that overeducation at an early stage of firm tenure-regarded in a theoretical framework of career mobility (Sicherman \& Galor, 1990)—yields positive returns for both employee and employer ${ }^{15}$.

As a general conclusion, labor economists should reconsider their assumptions about the lower productivity of overeducated employees ${ }^{16}$, as should personnel managers in Germany, where the overqualification of applicants is still a major reason for rejection. The results presented in this study suggest that such behavior is irrational. 
References

Alba-Ramirez, Alfonso. (1993). Mismatch in the Spanish labor market: Overeducation? Journal of Human Resources, 28(2), 259-278.

Bodenhöfer, Hans-Joachim. (1983). Unternehmenswachstum, Qualifikationsstruktur und Absorption eines höheren Qualifikationsangebots. In Widmaier, Hans Peter (Ed.), Das

Arbeitskräfteangebot zwischen Markt und Plan (pp.11-60). Berlin: Duncker \& Humblot.

Büchel, Felix. (1998). Zuviel gelernt? Ausbildungsinadäquate Erwerbstätigkeit in Deutschland. Bielefeld: W. Bertelsmann.

Büchel, Felix. (forthcoming). Overqualification—reasons, measurement issues, and typological affinity to unemployment. In Tessaring, Manfred \& Descy, Pascaline (Eds.), Second Report on Vocational Training Research in Europe. Thessaloniki (Greece): CEDEFOP.

Büchel, Felix \& Mertens, Antje. (2000). Overeducation, undereducation, and the theory of career mobility. Paper presented at the First EALE/SOLE World Conference, 22-25 June 2000, Milan, Italy.

Büchel, Felix \& Weißhuhn, Gernot. (1998). Ausbildungsinadäquate Beschäftigung der Absolventen des Bildungssystem II. Fortsetzung der Berichterstattung zu Struktur und Entwicklung unterwertiger Beschäftigung in West- und Ostdeutschland: (1993-1995). Report on behalf of the Federal Ministry of Education, Science, Research, \& Technology (BMBF). Vol. 471/II of the Series "Volkswirtschaftliche Schriften". Berlin: Duncker \& Humblot.

Coburn, David. (1975). Job-worker incongruence: Consequences for health. Journal of Health and Social Behavior, 16, 198-212.

Cohn, Elchanan. (1992). The impact of surplus schooling on earnings: Comment. The Journal of Human Resources, 27(4), 679-682.

Daly, Mary C., Büchel, Felix, \& Duncan, Greg J. (2000). Premiums and penalties for surplus and deficit education. Evidence from the United States and Germany. In Oosterbeek, Hessel (Ed.), The economics of over- and underschooling. Special Issue of Economics of Education Review, 19(2), 169-178.

Duncan, Greg J. \& Hoffmann, Saul D. (1981). The incidence and wage effects of overeducation. Economics of Education Review, 1(1), 75-86.

Franz, Wolfgang. (1991). Arbeitsmarktökonomik. Berlin: Springer.

Freeman, Richard B. (1976). The overeducated American. New York: Academic Press.

Gill, Andrew M. \& Solberg, Eric J. (1992). Surplus schooling and earnings: A critique. The Journal of Human Resources, 27(4), 683-689.

Greene, William H. (1993). Econometric analysis. New York: Macmillan.

Groot, Wim \& Maassen van den Brink, Henriette. (2000). Overeducation in the labor market: A meta-analysis. In Oosterbeek, Hessel (Ed.), The economics of over- and underschooling. Special Issue of Economics of Education Review, 19(2), 149-158. 
Hartog, Joop. (1985). Earnings functions: Testing for the demand side. Economics Letters, 19, 281285.

Hartog, Joop. (2000). Over-education and earnings: Where are we, where should we go? In Oosterbeek, Hessel (Ed.), The Economics of over- and underschooling. Special Issue of Economics of Education Review, 19(2), 131-148.

Haugrund, Stefan. (1990). Qualifikationsreserven in der industriellen Forschung und Entwicklung. Eine empirische Untersuchung zur Häufigkeit und zu ausgewählten Folgen einer arbeitsplatzbezogenen, individuellen Überqualifikation. Vol. 6 of the series "Management von Forschung, Entwicklung und Innovation", Brockhoff, Klaus \& Domsch (Eds.), Stuttgart: Michel.

Hersch, Joni. (1991). Education match and job match. Review of Economics and Statistics, 79, 140144.

House, J. (1974). The effects of occupational stress on physical health. In: O'Toole, J. (Ed.), Work and the quality of life. (pp. 145-170). Cambridge, MA: MIT Press.

Kasl, Stanislav V. (1974). Work and mental health. In: O'Toole, J. (Ed.), Work and the quality of life. (pp. 171-196). Cambridge, MA: MIT Press.

Kiker, Billy Frazier, Santos, Maria C., \& de Oliveira, M. Mendes. (1997). Overeducation and undereducation: Evidence for Portugal. Economics of Education Review, 16(2), 111-125.

Kornhauser, A. (1965). Mental health of the industrial worker. New York: Wiley.

Mangione, Thomas W. \& Quinn, Robert P. (1975). Job satisfaction, counterproductive behavior, and drug use at work. Journal of Applied Psychology, 60, 114-116.

Projektgruppe Panel. (1995). Das Sozio-oekonomische Panel (SOEP) im Jahre 1994. Vierteljahrshefte zur Wirtschaftsforschung, 64(1), 5-15.

Quinn, R. \& Mandilovitch, M. (1975). Education and job satisfaction: A questionable payoff. Michigan, Ann Arbor.

Rippe, Wolfgang. (1984). Die Analyse von betrieblichen Entscheidungsprozessen bei der Nachfrage von Hochschulabsolventen. Ein zu Recht vernachlässigter Ansatz bei der Erforschung von Absorptionsmechanismen des Arbeitsmarkts? In Widmaier, Hans Peter (Ed.), Das Arbeitskräfteangebot zwischen Markt und Plan. (pp. 61-96). Berlin: Duncker \& Humblot.

Rumberger, Russell W. (1981). Overeducation in the US labor market. New York: Praeger.

Rumberger, Russell W. (1987). The impact of surplus schooling on productivity and earnings. Journal of Human Resources, 22(1), 24-50.

Schwarze, Johannes. (1993). Qualifikation, Überqualifikation und Phasen des Transformationsprozesses. Die Entwicklung der Lohnstruktur in den neuen Bundesländern. In Jahrbücher für Nationalökonomie und Statistik, 211(1-2), 90-107.

Sicherman, Nachum. (1991). "Overeducation" in the labor market. Journal of Labor Economics, 9(2), 101-122. 
Sicherman, Nachum \& Galor, Oded. (1990). A theory of career mobility. Journal of Political Economy, 98(1), 169-192.

Thurow, Lester C. (1975). Generating inequality. Mechanisms of distribution in the U.S. economy. New York: Basic Books.

Tsang, Mun C. (1987). The impact of underutilization of education on productivity: A case study of the U.S. Bell companies. Economics of Education Review, 6(3), 239-254.

Tsang, Mun C. \& Levin, Henry M. (1985). The economics of overeducation. Economics of Education Review, 4(2), 93-104.

Tsang, Mun C., Rumberger, Russell W., \& Levin, Henry M. (1991). The impact of surplus schooling on worker productivity. Industrial Relations, 30(2), 209-228.

Verdugo, Richard R. \& Turner-Verdugo, Naomi. (1989). The impact of surplus schooling on earnings: Some additional findings. The Journal of Human Resources, 24(4), 629-643.

Verdugo, Richard R. \& Turner-Verdugo, Naomi. (1992). Surplus schooling and earnings: Reply to Cohn and to Gill \& Solberg. The Journal of Human Resources, 27(4), 690-695.

Vroom, Victor H. (1964). Work and motivation. New York: Wiley.

Wagner, Gert, Burkhauser, Richard V., \& Behringer, Friederike. (1993). The English language public use file of the German Socioeconomic Panel. Journal of Human Resources, 28(2), 429-433. 


\section{Table 1: Overeducation and Job Satisfaction in Low-Skill Jobs (West Germany, 1995, Ordered Logit)}

Covariates:

(Estimated bound I)

(Estimated bound II)

Age (years)

Age $* * 2(/ 100)$

Hauptschule certificate

(Realschule certificate)

Abitur certificate

Non-German

Poor health status

Male, married

(Male, other)

Female, living alone

Female, married, no children

Female, single parent

Female, married + children $<16$

Female, other

White collar

Regional unemployment rate

Rural area

Overeducated
Coeff. (Std Err) Odds

Mean

$\begin{array}{ll}0.124 & (.832) \\ 2.021 \star * & (.836) \\ -0.017 & (.039) \\ 0.027 & (.047) \\ 0.067 & (.140) \\ .0 & (.0) \\ -0.144 & (.388) \\ 0.186 & (.148) \\ -0.960 * \star & (.124) \\ 0.019 & (.185) \\ .0 .307 & (.308) \\ 0.267 & (.224) \\ -0.501 & (.322) \\ -0.039 & (.212) \\ 0.048 & (.222) \\ -0.071 & (.137) \\ -0.039 & (.028) \\ 0.384 * \star & (.122) \\ 0.047 & (.119)\end{array}$

$-$

0.983

1.028

1.070

0.866

1. 204

0.383

1.019

1. 360

1. 306

0.606

0.961

1.049

0.931

0.961

1. 468

1.048

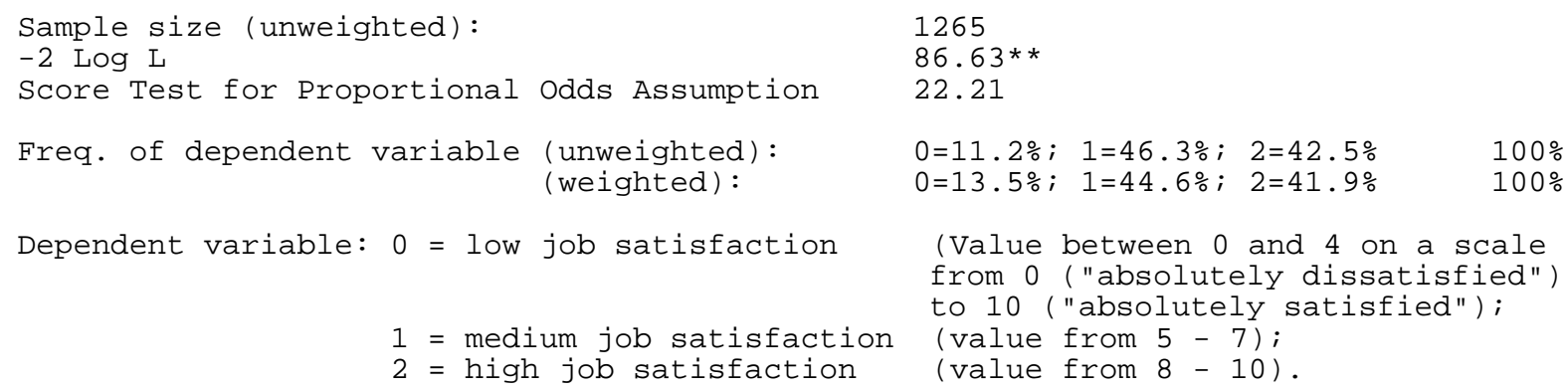

Levels of significance: **: $\mathrm{p}<0.01, *: \mathrm{p}<0.05,+: \mathrm{p}<0.10$.

Covariates in parentheses = reference categories.

Unweighted means of covariates as a documentation.

Only includes working people aged 16-65.

Excludes trainees and persons in education or formal training.

Excludes East Germans who moved to West Germany after 1989.

Excludes immigrant subsample "D" of GSOEP.

Source: Own calculations based on data from the German Socio-Economic Panel (GSOEP). 


\section{Table 2: Overeducation and Health Status in Low-Skill Jobs (West Germany, 1995, Binary Logit)}

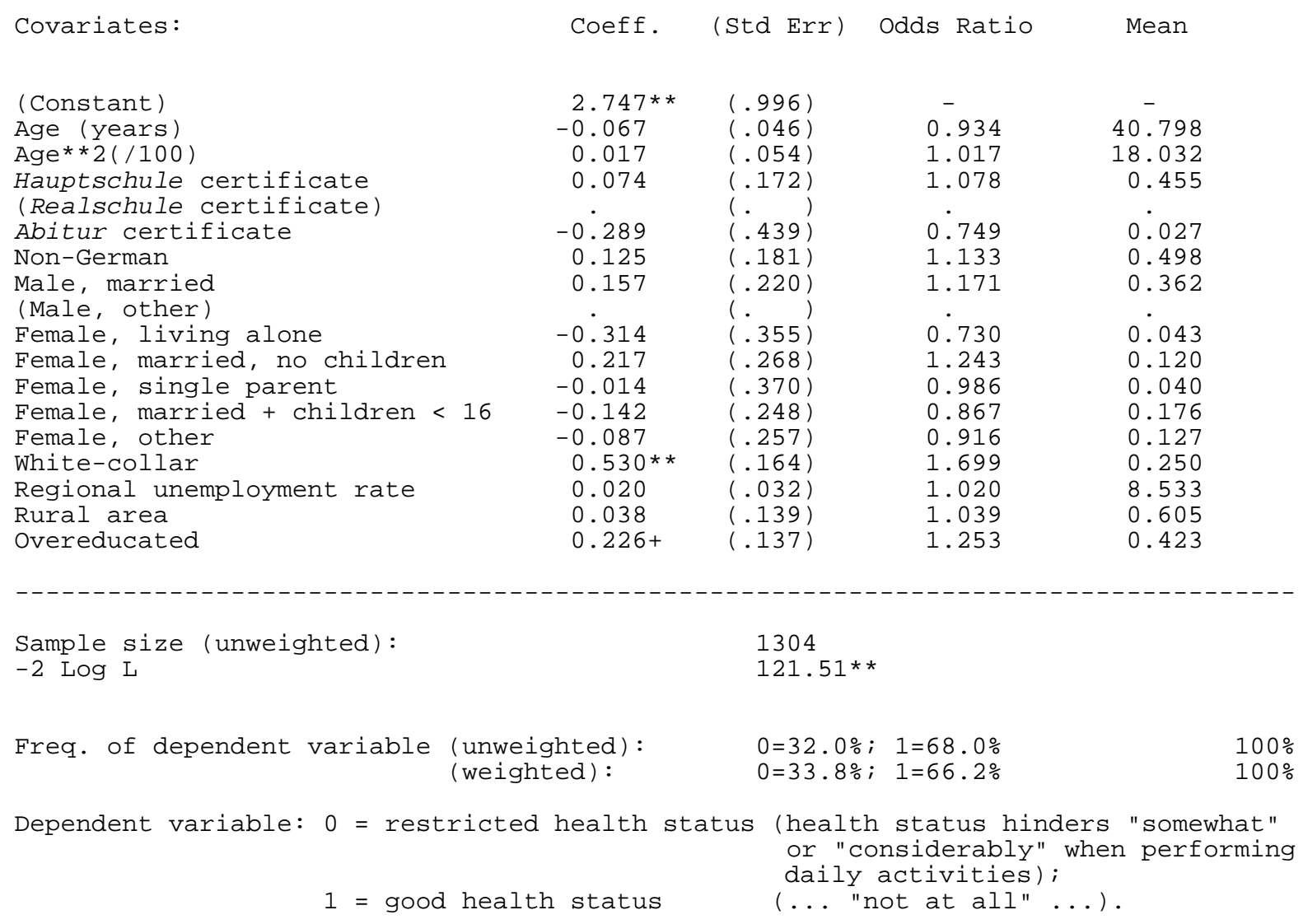

Levels of significance: **: $\mathrm{p}<0.01, *: \mathrm{p}<0.05,+\mathrm{p}<0.10$.

Covariates in parentheses = reference categories.

Unweighted means of covariates as a documentation.

Only includes working people aged 16-65.

Excludes trainees and persons in education or formal training.

Excludes East Germans who moved to West Germany after 1989.

Excludes immigrant subsample "D" of GSOEP.

Source: Own calculations based on data from the German Socio-Economic Panel (GSOEP). 
Table 3: $\quad$ Overeducation and Importance of Work and Occupational Success

for Well-Being and Satisfaction in Low-Skill Jobs

(West Germany, 1994, Ordered and Binary Logit)

\begin{tabular}{|c|c|c|c|c|c|c|c|}
\hline \multirow[b]{2}{*}{ Covariates: } & \multirow[b]{2}{*}{ Coeff. } & \multicolumn{4}{|c|}{ Importance of } & Success: & \multirow[b]{2}{*}{ Mean } \\
\hline & & (Std Err) & Odds $\mathrm{R}$. & Coeff. & (Std Err) & Odds R. & \\
\hline (Constant / Estim. Bound I) & $-1.388+$ & $(.835)$ & - & $1.954+$ & $(1.017)$ & - & - \\
\hline (Estimated Bound II) & 1.271 & $(.836)$ & - & - & - & - & - \\
\hline Age (years) & $0.071+$ & $(.039)$ & 1.075 & -0.019 & $(.046)$ & 0.981 & 41.133 \\
\hline Age $* * 2(/ 100)$ & $-0.103 *$ & $(.046)$ & 0.902 & -0.021 & $(.055)$ & 0.979 & 18.268 \\
\hline Hauptschule certificate & -0.110 & $(.141)$ & 0.896 & 0.228 & $(.175)$ & 1.256 & 0.456 \\
\hline (Realschule certificate) & & & & & & & \\
\hline Abitur certificate & $-0.695+$ & $(.371)$ & 0.499 & 0.414 & $(.490)$ & 1.514 & 0.026 \\
\hline Non-German & 0.115 & $(.148)$ & 1.122 & -0.219 & $(.183)$ & 0.803 & 0.502 \\
\hline Poor health status & 0.016 & $(.096)$ & 1.017 & -0.034 & $(.111)$ & 0.967 & 1.377 \\
\hline $\begin{array}{l}\text { Male, married } \\
\text { (Male, other) }\end{array}$ & $0.389 *$ & $(.191)$ & 1.476 & $0.752 * *$ & $(.236)$ & 2.121 & 0.368 \\
\hline Female, living alone & 0.289 & $(.314)$ & 1.336 & -0.210 & $(.359)$ & 0.810 & 0.043 \\
\hline Female, married, no children & 0.125 & $(.231)$ & 1.134 & 0.065 & $(.274)$ & 1.068 & 0.117 \\
\hline Female, single parent & -0.040 & $(.319)$ & 0.960 & 0.212 & $(.388)$ & 1.236 & 0.041 \\
\hline Female, married+children $<16$ & $-0.531 *$ & $(.214)$ & 0.588 & -0.374 & $(.249)$ & 0.688 & 0.179 \\
\hline Female, other & -0.368 & $(.228)$ & 0.692 & -0.304 & $(.262)$ & 0.737 & 0.129 \\
\hline White-collar & -0.207 & $(.137)$ & 0.813 & -0.099 & $(.163)$ & 0.905 & 0.249 \\
\hline Regional unemployment rate & -0.016 & $(.028)$ & 0.983 & 0.003 & $(.033)$ & 1.003 & 8.541 \\
\hline Rural area & -0.047 & $(.122)$ & 0.954 & -0.045 & $(.145)$ & 0.956 & 0.603 \\
\hline Overeducated & $0.221+$ & $(.120)$ & 1.248 & $0.269+$ & $(.145)$ & 1.309 & 0.421 \\
\hline
\end{tabular}

Sample size (unweighted):

1256

1249

Score Test for Prop. Odds Assumpt.

$61.98 * *$

$98.44 * \star$

33.11

Dependent variable:

"Importance of Work and Occupational Success, respectively, for Well-Being and Satisfaction"

Freq. of dependent variable: (unweighted) (weighted) (unweighted) (weighted)

Work is:

"Absolutely unimportant" or

"Less important" (0)

"Important"

"Very important"

(1) $49.3 \%$

$40.6 \%$

$10.4 \%$

$49.7 \%$

$39.9 \%$

Occupational Success is:

"Absolutely unimportant" or

"Less important" (0)

"Important/Very important" (1)

$\begin{array}{cc}- & - \\ - & \overline{-} \\ 100.0 \% & 100.0 \%\end{array}$

Levels of significance: **: $\mathrm{p}<0.01, *: \mathrm{p}<0.05,+: \mathrm{p}<0.10$.

Covariates in parentheses = reference categories.

Unweighted means of covariates as a documentation.

Only includes working people aged 16-65.

Excludes trainees and persons in education or formal training.

Excludes East Germans moving to West Germany after 1989.

Excludes immigrant subsample "D" of GSOEP.

Source: Own calculations based on data from the German Socio-Economic Panel (GSOEP). 
Table 4: $\quad$ Overeducation and Participation in On-the-job Training in Low-Skill Jobs (West Germany, 1987-1989 and 1991-1993, Binary Logit)

\begin{tabular}{|c|c|c|c|c|}
\hline Covariates: & Coeff. & (Std Err) & Odds Ratio & Mean \\
\hline (Constant) & $-4.936 *$ & $(2.100)$ & - & - \\
\hline Age (years) & 0.124 & $(.111)$ & 1.132 & 40.875 \\
\hline Age $\star \star 2(/ 100)$ & -0.221 & $(.146)$ & 0.802 & 17.966 \\
\hline Hauptschule certificate & 0.116 & $(.314)$ & 1.124 & 0.460 \\
\hline (Realschule certificate) & - & $(. \quad)$ & . & • \\
\hline Abitur certificate & $1.320 \star \star$ & $(.513)$ & 3.742 & 0.020 \\
\hline Non-German & $-0.975 \star \star$ & $(.369)$ & 0.377 & 0.509 \\
\hline Poor health status & $-0.513+$ & $(.310)$ & 0.599 & 0.393 \\
\hline Male, married & 0.427 & $(.419)$ & 1.533 & 0.39 \\
\hline (Male, other) & - & $(. \quad)$ & . & \\
\hline Female, living alone & 0.393 & $(.646)$ & 1.482 & 0.035 \\
\hline Female, married, no children & 0.039 & $(.556)$ & 1.040 & 0.09 \\
\hline Female, single parent & 0.248 & $(.704)$ & 1.282 & 0.03 \\
\hline Female, married + children $<16$ & -0.203 & $(.467)$ & 0.816 & 0.18 \\
\hline Female, other & -0.221 & $(.555)$ & 0.801 & 0.13 \\
\hline White-collar & $0.779 \star \star$ & $(.289)$ & 2.179 & 0.21 \\
\hline Regional unemployment rate & -0.042 & $(.061)$ & 0.958 & 6.89 \\
\hline Rural area & 0.052 & $(.283)$ & 1.054 & $0.56^{\circ}$ \\
\hline Year of interv.:1993 (otherw.:1989) & $0.648 *$ & $(.280)$ & 1.912 & 0.28 \\
\hline Overeducated & $0.592 *$ & $(.288)$ & 1.808 & 0.40 \\
\hline
\end{tabular}

Sample size(unweighted):

$-2 \log \mathrm{L}$

Freq. of dependent variable (unweighted): (weighted) :
1921

$87.00 * \star$

$0=96.5 \% ; 1=3.5 \%$

$0=94.5 \% ; 1=5.5 \%$
$100 \%$

$100 \%$

Dependent variable: 1 = person participated [in the three-year period preceding the interview] in an on-the-job training measure lasting at least more than one day; $0=$ (no participation).

Levels of significance: $* \star x: p<0.01, *: p<0.05,+: p<0.10$

Observation periods: $1987-1989$ for 1989 interviewees and 1991-1993 for 1993 interviewees [who did not participate in the 1989 interview].

Only includes persons in low-skill jobs who were working in 1989 or 1993 , respectively, in low-skill jobs and worked throughout the whole observation period.

Information on covariates gathered in 1989 and 1993, respectively.

Covariates in parentheses = reference categories.

Unweighted means of covariates as a documentation.

Only includes working people aged 16-65.

Excludes trainees and persons in education or formal training.

Excludes East Germans moving to West Germany after 1989.

Excludes immigrant subsample "D" of GSOEP.

Source: Own calculations based on data from the German Socio-Economic Panel (GSOEP). 


\section{IZA Discussion Papers}

No Author(s)

121 J. C. van Ours

122 D. Munich

J. Svejnar

K. Terrell

123 J. Hunt

124 R. T. Riphahn

125 F. Büchel

J. R. Frick

126 J. Fersterer

R. Winter-Ebmer

127 M. Karanassou

D. J. Snower

128 O. Ashenfelter

D. Ashmore

O. Deschênes

129 B. R. Chiswick

M. E. Hurst

130

G. Brunello

S. Comi

C. Lucifora

131

132

133

D. N. F. Bell

R. A. Hart

O. Hübler

W. Schwerdt

134 A. D. Kugler

G. Saint-Paul

135 A. Barrett

P. J. O'Connell

136 M. Bräuninger

M. Pannenberg
Titel

Area

Date

Do Active Labor Market Policies Help Unemployed $\quad 4 / 6$

Workers to Find and Keep Regular Jobs?

$3 / 00$

Returns to Human Capital under the Communist

4

$3 / 00$

Wage Grid and During the Transition to a Market

Economy

Why Do People Still Live in East Germany?

$3 / 00$

Rational Poverty or Poor Rationality? The Take-up 3

of Social Assistance Benefits

The Income Portfolio of Immigrants in Germany -

Effects of Ethnic Origin and Assimilation. Or:

Who Gains from Income Re-Distribution?

Smoking, Discount Rates, and Returns to

Education

Characteristics of Unemployment Dynamics: The

Chain Reaction Approach

Do Unemployment Insurance Recipients Actively

Seek Work? Evidence From Randomized Trials in

Four U.S. States

The Employment, Unemployment and

Unemployment Compensation Benefits of Immigrants

The Returns to Education in Italy: A New Look at 5 the Evidence

5

$3 / 00$

$3 / 00$

$3 / 00$

$3 / 00$

$3 / 00$

Are Immigrants Favorably Self-Selected? An 1

Economic Analysis

Hours and Wages in the Depression: British 7 Engineering, 1926-1938

Paid and Unpaid Overtime Working in Germany and 1 the UK

$3 / 00$

Hiring and Firing Costs, Adverse Selection and

3

$3 / 00$

Long-term Unemployment

Is There a Wage Premium for Returning Irish

1

$3 / 00$

Migrants?

Unemployment and Productivity Growth: An

3

$3 / 00$

Empirical Analysis within the Augmented Solow Model 
139 R. A. Hart

Y. Ma

140 G. Brunello

S. Comi

141 R. Hujer

M. Wellner

142 J. J. Dolado

F. Felgueroso

J. F. Jimeno

143 P. J. Luke

M. E. Schaffer

144 G. Saint-Paul

145 M.-S. Yun

146 T. K. Bauer

J. P. Haisken-DeNew

147 M. Belot

J. C. van Ours

148 L. Goerke

149 R. Lalive

J. C. van Ours

J. Zweimüller

150 J. DiNardo

K. F. Hallock

J.-St. Pischke

151 M. Ward

152 J. J. Dolado

F. Felgueroso

J. F. Jimeno

153 A. S. Kalwij

M. Gregory

154 M. Gerfin

M. Lechner
Wages, Hours and Human Capital over the

Life Cycle

Education and Earnings Growth: Evidence from 11

European Countries

The Effects of Public Sector Sponsored Training on Individual Employment Performance in East Germany

Explaining Youth Labor Market Problems in Spain: 3

Crowding-Out, Institutions, or Technology Shifts?

Wage Determination in Russia: An Econometric 4

Investigation

Flexibility vs. Rigidity: Does Spain have the worst of 1 both Worlds?

Decomposition Analysis for a Binary Choice Model 7

Employer Learning and the Returns to Schooling 5

Does the Recent Success of Some OECD

Countries in Lowering their Unemployment Rates

Lie in the Clever Design of their Labour Market

Reforms?

Employment Effects of Labour Taxation in an Efficiency Wage Model with Alternative Budget Constraints and Time Horizons

The Impact of Active Labor Market Programs and Benefit Entitlement Rules on the Duration of Unemployment

Unions and the Labor Market for Managers

Gender, Salary and Promotion in the Academic 5 Profession

The Role of the Minimum Wage in the Welfare 3 State: An Appraisal

Overtime Hours in Great Britain over the Period 3 1975-1999: A Panel Data Analysis

Microeconometric Evaluation of the Active Labour 6 Market Policy in Switzerland 
R. Rees

Household Production, Full Consumption and $\quad 7$

A Comparison of the Human Capital and Signaling Models: The Case of the Self-Employed and the Increase in the Schooling Premium in the 1980's 
174 E. Fehr J.-R. Tyran

175 M. Lofstrom

176

O. Hübler

W. Meyer

177 B. R. Chiswick

G. Repetto

178 R. Euwals

M. Ward

179 E. Wasmer

P. Weil

180 T. K. Bauer

I. N. Gang

181

E. Wasmer

Y. Zenou

182 M. Fertig

C. M. Schmidt

183 M. Fertig

184 M. Corak

B. Gustafsson

T. Österberg

185 H. Bonin

K. F. Zimmermann

186

C. Dustmann

187

T. K. Bauer

M. Lofstrom

K. F. Zimmermann
C. M. Schmidt

Does Money Illusion Matter? An Experimental

Approach

Self-Employment and Earnings among High-

Skilled Immigrants in the United States

Industrial Relations and the Wage Differentials

between Skilled and Unskilled Blue-Collar

Workers within Establishments: An Empirical

Analysis with Data of Manufacturing Firms

Immigrant Adjustment in Israel: Literacy and

Fluency in Hebrew and Earnings

The Renumeration of British Academics

5

The Macroeconomics of Labor and Credit Market Imperfections

Sibling Rivalry in Educational Attainment:

The German Case

Space, Search and Efficiency

2

$8 / 00$

Discretionary Measures of Active Labor Market Policy: The German Employment Promotion Reform in Perspective

Aggregate-Level Migration Studies as a Tool for 1 Forecasting Future Migration Streams

Intergenerational Influences on the Receipt of 3 Unemployment Insurance in Canada and Sweden

The Post-Unification German Labor Market

4

$8 / 00$

Temporary Migration and Economic Assimilation

$8 / 00$

Immigration Policy, Assimilation of Immigrants and 1

$8 / 00$

Natives' Sentiments towards Immigrants: Evidence from 12 OECD-Countries

The Myth of Worksharing

5

$8 / 00$

A. S. Kalwij

A. Zaidi 

190
C. Dustmann
I. Preston
191
G. C. Giannelli
C. Monfardini

192

G. Brunello

193

A. Kunze

194

A. Newell

F. Pastore

195 F. Büchel

A. Mertens

196 J. S. Earle

K. Z. Sabirianova

197
G. A. Pfann

M. Kreyenfeld

C. K. Spiess

G. G. Wagner

199 H. Entorf

200

T. Bauer

G. S. Epstein

I. N. Gang

201

T. J. Dohmen

G. A. Pfann

202

P. Francois

J. C. van Ours

203
J. M. Abowd
F. Kramarz
D. N. Margolis
T. Philippon

204

G. S. Epstein
A. L. Booth
M. Francesconi

J. Frank

206 C. M. Schmidt

R. Baltussen

R. Sauerborn
Racial and Economic Factors in Attitudes to

1

$8 / 00$

Immigration

Joint Decisions on Household Membership and

Human Capital Accumulation of Youths: The role of

expected earnings and local markets

Absolute Risk Aversion and the Returns to

5

$8 / 00$

Education

The Determination of Wages and the Gender

Wage Gap: A Survey

5

$8 / 00$

Regional Unemployment and Industrial

4

$8 / 00$

Restructuring in Poland

Overeducation, Undereducation, and the Theory

5

of Career Mobility

$9 / 00$

Equilibrium Wage Arrears: A Theoretical and 4 Empirical Analysis of Institutional Lock-In

$9 / 00$

Options to Quit

$9 / 00$

A Forgotten Issue: Distributional Effects of Day

3

Care Subsidies in Germany

$9 / 00$

Rational Migration Policy Should Tolerate Non-

$9 / 00$

Zero Illegal Migration Flows: Lessons from

Modelling the Market for Illegal Migration

What are Migration Networks?

$9 / 00$

Worker Separations in a Nonstationary Corporate 1 Environment

$9 / 00$

Gender Wage Differentials in a Competitive Labor 5 Market: The Household Interaction Effect

The Tail of Two Countries: Minimum Wages and 5 Employment in France and the United States

$9 / 00$

Labor Market Interactions Between Legal and

$10 / 00$ Illegal Immigrants

Temporary Jobs: Stepping Stones or Dead Ends? 1

$10 / 00$

The Evaluation of Community-Based Interventions: Group-Randomization, Limits and Alternatives 
